Avoimesti luettavissa osoitteessa http://journal.fi/ainedidaktiikka

ainedidaktiikka

\title{
Ilmastonmuutos lukion opetussuunnitelmissa ja maantieteen oppikirjoissa
}

\author{
Sirpa Tani ${ }^{1}$, Markus Hilander ${ }^{1}$ ja Julia Leivo ${ }^{2}$ \\ ${ }^{1}$ Kasvatustieteellinen tiedekunta, Helsingin yliopisto \\ ${ }^{2}$ Matemaattis-luonnontieteellinen tiedekunta, Helsingin yliopisto
}

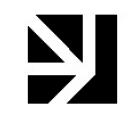

Oppikirjan merkitys suomalaisessa koulussa on perinteisesti ollut -ja yhä edelleen usein on - suuri: se, millaisia sisältöjä ja millaisia painotuksia oppikirjoissa esitetään, vaikuttaa vahvasti opetuksen etenemiseen. Tästä huolimatta oppikirjojen asiasisältöjä on tutkittu verrattain vähän. Ilmastonmuutoksen vakavuus on tunnustettu viime vuosina kansainvälisesti, ja tämä huoli on välittynyt myös koulutuksen ja kasvatuksen kentälle. On pohdittu sitä, mitä ilmastonmuutoksesta tulisi tietää, ja kenen vastuulla ilmastonmuutokseen liittyvien aiheiden opettaminen on. Tässä artikkelissa tarkastelemme, miten ilmastonmuntosta käsitellään kahdessa suomalaisessa lukion pakollisen maantieteen kurssin oppikirjassa (GEOS ja Manner). Tulosten mukaan oppikirjat eroavat selvästi siinä, millaista tietoa ilmastonmuutoksesta ne sisältävät, millaisia havainnollistamisen keinoja niissä käytetään ja millaisen painoarvon ne antavat yksilölle ja yhteiskunnalle ilmastonmuutoksen hillinnässä ja siihen sopeutumisessa. Yksi suurimmista oppikirjojen puutteista on se, että ne eivät esittele riittävästi helposti toteutettavia ilmastonmuutoksen hillitsemisen keinoja. Tulevissa lukion opetussuunnitelman perusteissa (2019) ilmastonmuutos mainitaan lähes kuusinkertaisesti aiempaan opetussuunnitelmaan (2015) verrattuna. Tämä voi vaikuttaa lukion maantieteen pakollisen kurssin oppikirjojen sisältöihin lähitulevaisuudessa.

Ilmastonmuutos, lukion maantiede, opetussuunnitelma, oppikirja

Lähetetty: 10.12.2019

Hyväksytty: 7.5.2020

Vastuukirjoittaja: sirpa.tani@helsinki.fi

DOI: $10.23988 /$ ad. 88063 


\section{Johdanto}

Syksyllä 2018 julkaistiin hallitustenvälisen ilmastonmuutospaneeli IPCC:n raportti, jonka mukaan ilmaston lämpeneminen tulisi pysäyttää 1,5 asteeseen esiteollisen ajan tasoon verrattuna (IPCC, 2018). Eräs näkyvimmistä vaikuttajista julkisessa keskustelussa on ollut ruotsalainen koululainen Greta Thunberg, joka elokuussa 2018 aloitti koululakon kiinnittääkseen päättäjien huomiota ilmastonmuutoksen hillitsemisen välttämättömyyteen (Gessen, 2018). Thunbergin toiminnasta sai alkunsa kansainvälinen koululaisten liike, jonka suurimpana tapahtumana järjestettiin maaliskuussa 2019 lasten ja nuorten ilmastolakkoja ja -marsseja noin 120 maassa (Rimaila, 2019). Thunberg korosti toiminnassaan poliittisten päättäjien vastuuta, jotta hiilidioksidipäästöt saataisiin laskettua vuoden 2015 Pariisin ilmastosopimuksen tasolle. Kysyttäessä syitä siihen, miksei hän mennyt kouluun, Thunberg vastasi: "What am I going to learn in school? Facts don't matter anymore, politicians aren't listening to the scientists, so why should I learn?" (Crouch, 2018). Ilmastolakossa ei siis ollut kyse siitä, etteikö nuorilla olisi riittävästi tietoa ilmastonmuutoksesta, vaan siitä, että kaikesta tiedosta huolimatta aikuiset, joilla on nuoria enemmän mahdollisuuksia tehdä poliittisia päätöksiä, eivät Thunbergin ja muiden nuorten mukaan toimineet riittävän tehokkaasti.

Vuoden 2018 Nuorisobarometrin mukaan suomalaisnuorten huoli ilmastonmuutoksesta on kasvanut selvästi aiempaa korkeammalle tasolle. Tutkimukseen osallistuneista nuorista peräti 68 prosenttia kertoi kokevansa epävarmuutta tai turvattomuutta ihmisestä johtuvan ilmastonmuutoksen vuoksi joko melko paljon tai erittäin paljon (Pekkarinen \& Myllyniemi, 2019, s. 74). Barometrin aineisto oli kerätty ennen syksyllä 2018 voimistunutta ilmastonmuutoskeskustelua (Piispa \& Myllyniemi, 2019), joten huolestuneisuuden voitaneen olettaa kasvaneen yhä suuremmaksi barometrin aineiston keruun jälkeen.

Suomessa keskustelun vilkkain aika osui keväällä 2019 käytyihin eduskuntavaaleihin, mikä sai puolueet ottamaan tavallista vahvemmin kantaa siihen, miten yhteiskunnan tulisi reagoida ilmastonmuutokseen. Samaan aikaan julkaistiin myös kansalaisaloite, jossa esitettiin ilmastooppia uudeksi kouluaineeksi (Kansalaisaloite, 2019). Ajatus erillisestä ilmastonmuutokseen keskittyvästä oppiaineesta nostaa esiin kysymyksen siitä, miten ilmastonmuutosta käsitellään nykykouluissa. Koska ilmastonmuutos on moniulotteinen ilmiö, sen opettaminen ainoastaan jonkin yksittäisen oppiaineen näkökulmasta saattaa muodostaa opiskelijoille vaillinaisen käsityksen ilmiön syntymekanismeista ja siihen liittyvistä syyseuraussuhteista.

Tutkijat ovat osoittaneet lukuisia ilmastonmuutokseen liittyviä virhekäsityksiä sekä oppilailla että opettajiksi opiskelevilla (esim. Hermans, 2016; Ratinen, 2016). Kasvihuoneilmiö mielletään usein virheellisesti ainoastaan ympäristöongelmaksi, ja esimerkiksi otsonikadon, ilmansaasteiden ja roskaamisen rooliin liittyy monia väärinymmärryksiä (Ratinen \& Vettenranta, 2018). On myös osoitettu, kuinka 
tiedot ilmastonmuutoksen hillinnän keinoista ovat puutteellisia sekä oppilailla (Ratinen \& Uusiautti, 2020) että opettajiksi opiskelevilla (Tolppanen, Claudelin \& Kang, 2020). Ratinen (2016) onkin korostanut, että ilmastonmuutoksen ymmärtäminen vaatii riittävää ymmärrystä ilmiöön vaikuttavista luonnontieteellisistä prosesseista.

Tässä artikkelissa tarkastelemme ilmastonmuutoksen käsittelyä lukio-opetuksessa ja erityisesti maantieteen oppikirjoissa. Olemme kiinnostuneita siitä, millaisia sisältöjä ja käsittelytapoja oppikirjat liittävät ilmastonmuutosta käsitteleviin osuuksiin. Tarkastelemme sitä, tarjoavatko nykyiset kirjat riittävästi tietoa ilmastonmuutoksesta, siihen vaikuttavista tekijöistä ja sen hillitsemisen keinoista. Oppikirjan asema suomalaisissa kouluissa on perinteisesti ollut hyvin vahva, ja sitä se on edelleen: se vaikuttaa huomattavasti opetuksen sisältöön ja etenemisjärjestykseen. Oppikirjoihin valitut käsitteet ja aiheiden painotukset helpottavat opettajan työtä opetuksen suunnitteluvaiheessa (Cantell, 2014, s. 84). Samalla oppikirjat tulkitsevat opetussuunnitelmaa. Ne korostavat joitakin opetussuunnitelmassa mainittuja sisältöjä, mutta samalla saattavat jättää jotkin toiset sisällöt vähemmälle huomiolle. Huolimatta siitä, että oppikirjat ovat tärkeitä opetuksen suunnittelussa ja toteutuksessa, niitä on tutkittu yllättävän vähän (Hiidenmaa, 2014, s. 27). Rinteen (2019, ss. 74-75) mukaan aiemmissa tutkimuksissa on tarkasteltu erityisesti oppikirjojen ymmärrettävyyttä, mutta ei niinkään oppikirjojen asiasisältöjä.

Esittelemme seuraavaksi keskeisimpiä näkökulmia, joita ilmastonmuutoksen opetuksen tutkimuksissa on aiemmin tuotu esiin. Sen jälkeen pohdimme eheyttävän ja tiedonalalähtöisen opetuksen merkitystä ilmastonmuutoksen käsittelyssä. Ennen oppikirja-analyysiamme esittelemme lyhyesti ilmastonmuutoksen asemaa tällä hetkellä voimassa olevissa ja tulevissa lukion opetussuunnitelman perusteissa. Empiirisenä aineistonamme ovat kahden kustantajan julkaisemat, nykyistä opetussuunnitelmaa noudattavat lukion maantieteen oppikirjat.

\section{Ilmastonmuutoksen opetukseen liittyvästä tutkimuksesta}

Ilmastonmuutoksen opetusta on tutkittu jonkin verran sekä Suomessa että kansainvälisesti. Ratinen (2016; ks. myös Ratinen, Viiri \& Lehesvuori, 2013) on tutkinut luokanopettajaopiskelijoiden ilmastonmuutokseen liittyviä käsityksiä ja havainnut, että ilmastonmuutoksen ymmärtäminen edellyttää opettajiksi opiskelevilta ilmiöön vaikuttavien luonnontieteellisten prosessien perusteiden riittävää ymmärrystä. Lehtonen ja Cantell (2015) ovat tarkastelleet ilmastokasvatuksen asemaa erityisesti peruskoulun opetussuunnitelmissa. Samassa yhteydessä he ovat kiinnittäneet huomiota siihen, kuinka ilmastonmuutoksen käsittely oli heidän tutkimuksensa aikaan luonnosvaiheessa olleessa lukion opetussuunnitelmassa varsin vähäistä, ja kuinka ilmastonmuutos mainittiin velvoittavana tavoitteena ainoastaan lukiomaantieteessä (Lehtonen \& Cantell, 2015, s. 13).

Myös Aarnio-Linnanvuori (2018) on kiinnittänyt huomiota ilmastonmuutoksen vähäiseen käsittelyyn opetussuunnitelmissa. Hän analysoi 
väitöskirjassaan ympäristöopetusta katsomusaineiden, historian, yhteiskuntaopin ja taloustiedon oppikirjoissa sekä haastatteli näiden aineiden opettajia sekä muutamaa maantieteen opettajaa. Aarnio-Linnanvuoren (2018) mukaan ilmastonmuutos tuli yhtenä ympäristöopetukseen liittyvänä teemana kyllä esiin sekä oppikirjoissa että opettajien haastatteluissa, mutta ilmastonmuutosta kuten muitakin ympäristöaiheita käsiteltiin hyvin vähän oppikirjoissa, ja kirjoissa esiintyi hänen mukaansa myös asiavirheitä ilmastonmuutoksen käsittelyn yhteydessä. Osa opettajista piti ympäristöaiheita nimenomaan luonnontieteisiin kuuluvina, eikä sen vuoksi kokenut niiden liittyvän omaan oppiaineeseensa (Aarnio-Linnanvuori, 2018, s. 76).

Ilmastonmuutokseen liittyviä teemoja on tutkittu myös kansainvälisessä opetuksen tutkimuskirjallisuudessa. Romàn ja Busch (2016) ovat analysoineet keskikoulun (middle school) kuudennen luokan luonnontieteen oppikirjojen tapaa käsitellä ilmastonmuutosta Yhdysvalloissa. Heidän mukaansa oppikirjat välittivät käsityksiä siitä, kuinka tiedeyhteisön piirissä ei ollut yksimielisyyttä ilmastonmuutoksen olemassaolosta eikä ihmisen vaikutuksesta sen kiihtymiseen (Romàn \& Busch, 2016). Lienee aiheellista huomauttaa, että heidän tutkimuksensa aineistona olivat ainoastaan neljän oppikirjan sisältämät, ilmastonmuutokseen liittyvät tekstit. Nämä kirjat oli julkaistu vuosina 2007 ja 2008, minkä jälkeen ilmastonmuutoksesta on tullut yleisesti tiedeyhteisön todentama ilmiö, jonka kiihtymiseen ihmisen toiminnalla on ollut ratkaiseva merkitys.

Meehan, Levy ja Collet-Gildard (2018) ovat analysoineet sekä yhdysvaltalaisia luonnontieteiden että yhteiskuntatieteiden (social studies) lukiokoulutuksen oppikirjoja ja lisämateriaaleja. He havaitsivat suuria eroja opetusmateriaaleissa siinä, millaisesta näkökulmasta ne käsittelivät ilmastonmuutosta. Jotkut materiaalit painottivat heidän mukaansa ihmisen toiminnan roolia ilmiön voimistumisessa, kun puolestaan osa materiaaleista keskittyi esittelemään ilmastonmuutoksen syntymekanismeja, mutta ei ilmiön vaikutuksia ympäristöön. Ilmastonmuutoksen ehkäisemiseen tai hillintään kiinnitettiin huomiota vain harvoin. Bagoly-Simó $(2013 ; 2014)$ on puolestaan tutkinut ilmastonmuutosta meksikolaisissa, romanialaisissa ja saksalaisissa maantieteen oppikirjoissa ja opetussuunnitelmissa yläkoulutasolla. Hänen mukaansa useimmissa analysoiduissa oppikirjoissa ilmastonmuutoksen syitä käsiteltiin lähinnä ihmisen toiminnan aiheuttamina ja koska ilmastonmuutosta ei ollut eksplisiittisesti mainittu opetussuunnitelmissa, se ei myöskään käsitteenä yleensä ollut siirtynyt oppikirjoihin.

Ilmastonmuutoksen käsittelyä suomalaisissa maantieteen oppikirjoissa on aiemmin tutkinut Ikonen (2009). Hän analysoi kahtakymmentä lukion oppikirjaa, jotka oli julkaistu vuosina 1954-2005. Hänen mukaansa ilmastonmuutoksen käsittely oli lisääntynyt vuosikymmenten kuluessa. Myös käsiteltävät aiheet vaihtuivat ajan kuluessa: 1980-luvun ja sitä vanhemmissa kirjoissa keskityttiin lähinnä ilmastonmuutosta aiheuttavien tekijöiden kuvaukseen, kun puolestaan 1990- ja 2000-luvuilla julkaistuissa kirjoissa painotettiin ilmastonmuutoksen vaikutuksia ja niiden hallinnan keinoja (Ikonen, 2009, s. 54).

Edellä esittelemämme tutkimustulokset osoittavat, kuinka oppimateriaaleissa ei näytä olevan vakiintuneita tapoja ilmastonmuutoksen käsittelyyn. Tutkimusten mukaan ilmastokasvatus on usein myös 
puutteellista ja kapea-alaista. Tämän takia tutkijat ovat kehittäneet uusia, tutkimuskirjallisuuteen perustuvia ilmastokasvatuksen malleja, kuten ratkaisukeskeisen ilmastokasvatuksen prosessimallin (Ratinen, Kinni, Muotka \& Sarivaara, 2019) ja kokonaisvaltaisen ilmastokasvatuksen polkupyörämallin (Tolppanen, Aarnio-Linnanvuori, Cantell \& Lehtonen, 2017; Cantell, Tolppanen, Aarnio-Linnanvuori \& Lehtonen, 2019). Esittelemme seuraavaksi tarkemmin polkupyörämallia, johon heijastamme myöhemmin analyysimme tuloksia.

Polkupyörämallissa polkupyörää ja sen osia on käytetty kuvaamaan sitä, kuinka jokaisella ilmastokasvatuksen osa-alueella on oma tehtävänsä ja kuinka kaikkia osia tarvitaan, jotta polkupyörä saadaan liikkeelle. Tuloksekas ilmastokasvatus edellyttää siis kaikkien mallin osa-alueiden huomioon ottamista.

Opiskelijan identiteetti, hänen arvonsa ja maailmankuvansa muodostavat mallissa polkupyörän rungon, johon uudet tiedot ja ajattelun taidot (polkupyörän pyörät) kiinnittyvät. Huolimatta siitä, että ilmastonmuutoksen ymmärtäminen edellyttää ilmiöön liittyvien perustietojen hallintaa, mallin kehittäjät tuovat esiin, kuinka tieto ei voi olla ilmastokasvatuksen itsetarkoitus. Sen rinnalla tarvitaan kykyä analysoida ja arvioida tietoja kriittisesti; tätä kautta ilmastonmuutokseen liittyvä ymmärrys voi lisääntyä (Cantell ym., 2019, s. 718).

Polkupyörän ketjuilla ja polkimilla kuvataan ilmastonmuutoksen hillintään liittyvää toimintaa. Jokainen, myös nuori oppija, voi osallistua ilmastonmuutoksen hillintään muuttamalla omia kulutustottumuksiaan tai osallistumalla yhteiskunnalliseen toimintaan. Aktiivinen toiminta edellyttää usein kannustamista ja ohjaamista. Polkupyörän satulalla kuvataan oppijan motivaatiota ja osallisuuden kokemuksia. Mallin kehittäjät kirjoittavat: "Jotta ilmastokasvatus olisi motivoivaa, sen ei tule kuvata ilmastonmuutosta etäisenä ongelmana eikä liian vaikeana ymmärtää. On olennaista korostaa, että koska ihmiset ovat rakentaneet yhteiskunnan, ihmiset pystyvät sitä myös muuttamaan." (Aarnio-Linnanvuori, Cantell, Lehtonen \& Tolppanen, 2018, s. 463).

Polkupyörämallissa kiinnitetään huomiota myös siihen, kuinka tärkeää on tiedostaa, millaiset seikat estävät tai hidastavat ilmastonmuutoksen hillitsemiseen liittyvää toimintaa: tätä kuvataan polkupyörän jarruilla. Lamppu puolestaan symbolisoi toivon ja muiden tunteiden merkitystä ilmastonmuutoksen opiskelussa. Koska ilmastonmuutos ilmiönä on monimutkainen ja toimii sekä globaalilla että paikallisella tasolla, siihen vaikuttamisen keinot voivat helposti tuntua liian rajallisilta tai hitailta. Näin syntyvä ilmastoahdistus (Pihkala, 2017; 2018) voi toimia oppimisen estäjänä. Polkupyörämallissa toivon ja myötätunnon tunteiden herättämistä pidetäänkin tärkeinä ilmastokasvatuksen osa-alueina. Ohjaustangolla viitataan tulevaisuusajattelun tärkeyteen ilmastokasvatuksessa: erilaisten skenaarioiden hahmottaminen ja niiden avulla tulevaisuuteen vaikuttaminen ovat keskeisiä keinoja, joilla ilmastonmuutoksen opiskelu ei aiheuta lannistumista, vaan tarjoaa pikemminkin keinoja siihen, kuinka ilmiöön voidaan vaikuttaa. 


\section{Ilmastonmuutos eheyttävän ja oppiainejakoisen opetuksen näkökulmasta}

Ilmastonmuutoksen opiskelu edellyttää eri tieteenalojen tuottaman tiedon omaksumista. Samalla se tuo myös esiin erilaisten tietojen yhdistämisen tarpeellisuuden: pelkkä luonnontieteellinen tieto ei riitä, vaan sen lisäksi tarvitaan myös tietoa sosiaalisista, poliittisista ja talouteen liittyvistä prosesseista, jotka vaikuttavat ilmastonmuutokseen (Mochizuki \& Bryan, 2015 , s. 13). Se, millainen rooli annetaan toisaalta yksittäisiin tieteenaloihin perustuvalle tiedolle ja toisaalta eri alojen rajojen ylittämiselle opetuksessa ja opiskelussa, nostaa esiin kysymyksen oppiainejakoisesta ja eheyttävästä opetuksesta (Cantell, 2015).

Eheyttäminen eli integroiminen on viime aikoina usein mielletty niin sanotuksi ilmiöopiskeluksi tai ilmiölähtöiseksi eheyttämiseksi (esim. Lonka, 2018; Niemelä \& Tirri, 2018), jossa lähtökohtana on jokin opetuksessa käsiteltävä, usein monimutkainen ilmiö - esimerkiksi ilmastonmuutos. Yhteisöllisellä tiedon rakentamisella pyritään monimutkaisen ilmiön kokonaisvaltaiseen ymmärtämiseen.

Integroivaa opetusta voidaan toteuttaa myös tiedonalalähtöisellä eheyttämisellä, jossa huomio on kunkin tiedon- ja tieteenalan peruskäsitteistössä (Tani, 2017, s. 217). Tiedonalalähtöiseen eheyttämiseen tähtäävä opetus lähtee liikkeelle tiedonalojen tärkeimpien käsitteiden ja prosessien ymmärtämisestä, minkä jälkeen näitä käsitteitä käytetään maailman monimutkaisten ilmiöiden haltuunotossa (Juuti, Kairavuori \& Tani, 2015, s. 79). Tiedonalalähtöisen eheyttämisen tavoitteena on siten auttaa opiskelijaa ymmärtämään maailmaa eri tiedonalojen kannalta merkityksellisten ajattelutapojen ja näkökulmien kautta. Tiedonalalähtöinen eheyttäminen on jossain määrin tieto-opillisesti sama asia kuin teoriatriangulaatio, jossa samaa ilmiötä tai tutkimusaineistoa tarkastellaan usean teorian näkökulmasta (Juuti, Kairavuori \& Tani, 2015, s. 82).

Sekä ilmiö- että tiedonalalähtöisellä eheyttämisellä on oma paikkansa ilmastonmuutoksen opiskelussa. Näistä ensimmäisen etuna voidaan pitää selkeää pyrkimystä suurten ja monimutkaisten kokonaisuuksien ymmärtämiseen, mutta haasteena voi olla esimerkiksi koulunpidon käytännöt: aikataulujen yhteensovittaminen eri oppiaineiden opettajien kesken, yhteissuunnitteluun liittyvät haasteet sekä opetussuunnitelman oppiainekohtaiset tavoitteet ja sisällöt. Ilmiölähtöisen eheyttämisen haasteena voi myös olla riittävän syvällisen luonnontieteellisen perustiedon puuttuminen, mikä voi vaikeuttaa ilmastonmuutoksen ymmärtämistä ja aiheuttaa monia virhekäsityksiä (Ratinen, 2016).

Tiedonalalähtöinen eheyttäminen voi, ainakin periaatteessa, mahdollistaa riittävän syvällisen ymmärryksen rakentamisen ilmastonmuutokseen vaikuttavista tekijöistä samalla kun sen seurauksia sekä hillitsemisen keinoja voidaan tarkastella monialaisesti. Haasteena tässäkin ovat samat käytännön ongelmat kuin ilmiölähtöisessä eheyttämisessä: opettajien välisen toimivan yhteistyön toteuttaminen vaatii paneutumista opetuksen suunnitteluun yhdessä, mikä edellyttää monien koulun käytäntöjen ajattelemista uudella tavalla. 
Suomalaisessa kasvatus- ja koulutuspoliittisessa keskustelussa on viime vuosina korostettu toistuvasti eheyttävän opiskelun merkitystä. Viimeisimmässä opetussuunnitelmauudistuksessa peruskoulun keskeiseksi tavoitteeksi nostettiin laaja-alainen osaaminen, joka edellyttää "tiedon- ja taidonalat ylittävää ja yhdistävää osaamista” sekä eheyttäminen, jonka avulla on tarkoitus "tehdä mahdolliseksi opiskeltavien asioiden välisten suhteiden ja keskinäisten riippuvuuksien ymmärtäminen" (Opetushallitus, 2014, ss. 20, 31). Huolimatta siitä, että laaja-alaisen oppimisen ja oppiaineiden rajojen ylittämisen tärkeyttä on korostettu koko yleissivistävässä koulutuksessa, eheyttämiskeskustelussa on painotettu erityisesti perusopetuksen kontekstia.

Monimutkaisten ilmiöiden, esimerkiksi ilmastonmuutoksen ja globalisaation, käsittely on tuonut ajatukset eheyttämisen tarpeellisuudesta myös lukio-opintojen suunnitteluun. Lukiossa eheyttämistä toteutetaan oppiainerajat ylittävien aihekokonaisuuksien ja teemaopintojen avulla. Aihekokonaisuudet on määritelty yhteiskunnallisesti merkittäviksi kasvatus- ja koulutushaasteiksi ja ajankohtaisiksi arvokannanotoiksi, joiden tavoitteina on "ymmärtää asioiden välisiä yhteyksiä, vuorovaikutussuhteita ja keskinäisriippuvuuksia" sekä "osata jäsentää laaja-alaisia kokonaisuuksia tiedon- ja taidonalat ylittävästi ja yhdistävästi” (Opetushallitus, 2015, s. 35). Teemaopintojen tarkoituksena on kehittää "opiskelijoiden taitoja hahmottaa ja ymmärtää yksittäistä oppiainetta laajempia kokonaisuuksia" (Opetushallitus, 2015, s. 220). Lukiossa oppiainejakoinen opetus on säilyttänyt asemansa näihin päiviin saakka melko muuttumattomana, mitä edellä kuvattujen aihekokonaisuuksien ja teemaopintojen esiintuominen on tosin jonkin verran haastanut. Tulevaisuudessa laaja-alaisen osaamisen teemojen sitominen kunkin oppiaineen tavoitteisiin ja sisältöihin (Opetushallitus, 2019) lisännee pyrkimyksiä oppiaineiden rajojen ylittämiseen.

\section{Ilmastonmuutos opetussuunnitelmissa}

Ilmastonmuutos tuli peruskoulun opetussuunnitelmiin vuonna 2014. Aiemmassa opetussuunnitelmassa termiä ei mainittu lainkaan (Opetushallitus, 2004). Nykyisessä suunnitelmassa ilmastonmuutos tulee esiin peruskoulun arvoperustassa kestävän elämäntavan välttämättömyyden kuvauksessa, alakoulun ympäristöopissa sekä yläkoulun biologiassa ja maantiedossa (Opetushallitus, 2014; Lehtonen \& Cantell, 2015). Vuoden 2003 lukion opetussuunnitelman perusteissa ilmastonmuutos mainittiin kerran: yhdellä sanalla maantieteen ensimmäisen kurssin sisällöissä (Opetushallitus, 2003). Tällä hetkellä voimassa olevassa lukion opetussuunnitelmassa ilmastonmuutos on tuotu esille kuvattaessa koulun arvoperustaa:

"Opiskelija ymmärtää oman toimintansa ja globaalin vastuun merkityksen luonnonvarojen kestävässä käytössä, ilmastonmuutoksen hillinnässä ja luonnon monimuotoisuuden säilyttämisessä." (Opetushallitus, 2015, s. 13)

Tämän lisäksi ilmastonmuutos on liitetty "Kestävä elämäntapa ja globaali vastuu" -aihekokonaisuuden tavoitteiden kuvaukseen (Opetushallitus, 2015, s. 37): 
Ainedidaktiikka 4(2) (2020)

"Tavoitteena on, että opiskelija tuntee ilmastonmuutokseen ja luonnon monimuotoisuuden heikkenemiseen vaikuttavia tekijöitä sekä tiedostaa niiden merkityksen ympäristölle ja ihmisen toiminnalle."

Se, miten yllä mainitut tavoitteet toteutuvat opetuksessa, jää käytännössä opetuksen toteuttajan ja erityisesti yksittäisten oppiaineiden opettajien vastuulle. Ilmastonmuutos mainitaan näiden yleisten arvo- ja aihekokonaisuustekstien lisäksi ainoastaan biologiassa ja maantieteessä. Biologian toisessa kurssissa, joka käsittelee ekologiaa ja ympäristöä, ilmastonmuutoksen ekologiset vaikutukset on liitetty ympäristöongelmien syitä ja ratkaisumahdollisuuksia käsittelevään keskeiseen sisältöalueeseen (Opetushallitus, 2015, s. 142). Lukion maantieteen pakollisen Maailma muutoksessa -kurssin yhteydessä ilmastonmuutos mainitaan luonnonvaroihin ja ympäristöön liittyvien keskeisten globaalien riskialueiden, riskien hillinnän sekä niihin varautumisen ja sopeutumisen yhteydessä (Opetushallitus, 2015, s. 148). Kaiken kaikkiaan voidaan todeta, kuinka ilmastonmuutoksen käsittelyä ei vielä nostettu kovinkaan tärkeäksi teemaksi vuoden 2015 lukion opetussuunnitelmassa.

Marraskuussa 2019 Opetushallitus julkaisi uudet lukion opetussuunnitelman perusteet, jotka otetaan käyttöön vuonna 2021. Huolimatta siitä, että artikkelimme empiirinen aineisto perustuu vuoden 2015 opetussuunnitelmaa noudattavien oppikirjojen analyysiin, on kuitenkin mielenkiintoista tarkastella sitä, miten ilmastonmuutoskeskustelu on heijastunut uusiin suunnitelmiin. Muutos on selkeä: kun vuoden 2015 suunnitelmassa ilmastonmuutos mainitaan neljä kertaa, uudessa opetussuunnitelmassa se on mainittu 23 kertaa (Taulukko 1).

Taulukko 1. Ilmastonmuutos tulevissa lukion opetussuunnitelman perusteissa (Opetushallitus, 2019).

\begin{tabular}{|c|c|}
\hline $\begin{array}{l}\text { Opetussuunnitelman osa, } \\
\text { jossa ilmastonmuutos } \\
\text { mainitaan }\end{array}$ & $\begin{array}{l}\text { Lainaus opetussuunnitelman tekstistä } \\
\text { (Opetushallitus, 2019) }\end{array}$ \\
\hline Arvoperusta & $\begin{array}{l}\text { "Opiskelija ymmärtää oman toimintansa ja globaalin } \\
\text { vastuun merkityksen luonnonvarojen kestävässä käy- } \\
\text { tössä, ilmastonmuutoksen hillinnässä ja luonnon } \\
\text { monimuotoisuuden säilyttämisessä." (s. 17) }\end{array}$ \\
\hline $\begin{array}{l}\text { Toinen kotimainen kieli, } \\
\text { ruotsi/ } \\
\text { Toinen kotimainen kieli, } \\
\text { suomi/ } \\
\text { Vieraat kielet: } \\
\text { "Laaja-alainen osaaminen } \\
\text { oppiaineessa" }\end{array}$ & $\begin{array}{l}\text { "Globaalit ympäristökysymykset, kuten ilmastonmuu- } \\
\text { tos, luonnon monimuotoisuuden väheneminen sekä } \\
\text { kestämättömät kulutustottumukset, ovat yksilöön ja } \\
\text { yhteisöihin vaikuttavia ongelmia." (ss. 128, 151, 176) }\end{array}$ \\
\hline $\begin{array}{l}\text { Ruotsi, englanti, vieraat } \\
\text { kielet; } \\
\text { "Ympäristö ja kestävä } \\
\text { elämäntapa" -moduuli ( } 2 \text { op) }\end{array}$ & $\begin{array}{l}\text { Keskeisissä sisällöissä: "globaalit ympäristökysymyk- } \\
\text { set, esimerkiksi/kuten ilmastonmuutos" (ss. 135, 148, } \\
184,189,206)\end{array}$ \\
\hline $\begin{array}{l}\text { Biologia; Ihmisen vaikutuk- } \\
\text { set ekosysteemeihin } \\
\text {-moduuli ( } 1 \text { op) }\end{array}$ & $\begin{array}{l}\text { Keskeisissä sisällöissä: ’'Ihmisen aiheuttamat ekosys- } \\
\text { teemien muutokset ja ympäristöongelmien ratkaisu- } \\
\text { keinoja: }\end{array}$ \\
\hline
\end{tabular}


Ainedidaktiikka 4(2) (2020)

\begin{tabular}{|c|c|}
\hline & $\begin{array}{l}\text { ilmastonmuutoksen vaikutukset ekosysteemeihin" } \\
\text { (s. 238) }\end{array}$ \\
\hline $\begin{array}{l}\text { Maantiede: Maailma } \\
\text { muutoksessa -moduuli } \\
(2 \text { op) }\end{array}$ & $\begin{array}{l}\text { Keskeisissä sisällöissä: "Ympäristön muutoksia ja } \\
\text { niiden ratkaisukeinoja: } \\
\text { - } \quad \text { ilmastonmuutosten mekanismit } \\
-\quad \text { nykyisen ilmastonmuutoksen syitä ja } \\
\quad \text { seurauksia" (s. 245) }\end{array}$ \\
\hline $\begin{array}{l}\text { Fysiikka: Fysiikka, ympä- } \\
\text { ristö ja yhteiskunta -moduuli } \\
\text { (1 op) }\end{array}$ & $\begin{array}{l}\text { Keskeisissä sisällöissä: "energiantuotannon vaikutus } \\
\text { ympäristöön ja ilmastonmuutokseen" (s. 253) }\end{array}$ \\
\hline $\begin{array}{l}\text { Energia ja lämpö -moduuli } \\
(2 \mathrm{op})\end{array}$ & $\begin{array}{l}\text { "Keskeiset sisällöt liittyvät esimerkiksi energiantuo- } \\
\text { tantoon, ilmastonmuutokseen ja rakentamiseen." } \\
\text { (s. 253) }\end{array}$ \\
\hline $\begin{array}{l}\text { Kemia: "Laaja-alainen } \\
\text { osaaminen oppiaineessa", }\end{array}$ & $\begin{array}{l}\text { "Opiskelija tunnistaa kemian tarjoamia ratkaisuja eri- } \\
\text { laisiin ympäristöhaasteisiin, kuten ilmastonmuutok- } \\
\text { seen ja luonnonvarojen riittävyyteen." (s. 260) }\end{array}$ \\
\hline $\begin{array}{l}\text { Kemiallinen tasapaino } \\
\text {-moduuli }(2 \text { op })\end{array}$ & $\begin{array}{l}\text { "Moduulin keskeisiä sisältöjä voidaan tarkastella esi- } \\
\text { merkiksi seuraavissa yhteyksissä: vesi ja vedenpuh- } \\
\text { distus, happamoitumisen ja ilmastonmuutoksen } \\
\text { ehkäisy, savukaasujen puhdistus sekä lääkkeen tai } \\
\text { jonkin peruskemikaalin tuotantoprosessin tehokkuus } \\
\text { ja ympäristövaikutusten arvioiminen." (s. 263) }\end{array}$ \\
\hline $\begin{array}{l}\text { Filosofia: Etiikka -moduuli } \\
\text { ( } 2 \text { op) }\end{array}$ & $\begin{array}{l}\text { Keskeisissä sisällöissä: "ympäristöä ja luontoa koske- } \\
\text { via eettisiä kysymyksiä, kuten ilmastonmuutos ja } \\
\text { eläinten oikeudet" (s. 271) }\end{array}$ \\
\hline $\begin{array}{l}\text { Yhteiskuntaoppi: Suomi, } \\
\text { Eurooppa ja muuttuva } \\
\text { maailma -moduuli ( } 2 \text { op) }\end{array}$ & $\begin{array}{l}\text { Keskeisissä sisällöissä: "Globaalit haasteet, globali- } \\
\text { saatio ja verkottuminen: ympäristö, ilmastonmuutos, } \\
\text { väestö ja kestävä tulevaisuus" (s. 295) }\end{array}$ \\
\hline $\begin{array}{l}\text { Elämänkatsomustieto: } \\
\text { "Laaja-alainen osaaminen } \\
\text { oppiaineessa" }\end{array}$ & $\begin{array}{l}\text { "Oppiaineessa sekä aktivoidaan toimintaa ilmaston- } \\
\text { muutoksen torjumiseksi että pohditaan ilmastonmuu- } \\
\text { toksen kohtaamisen kannalta olennaisia asenteita ja } \\
\text { tunnetaitoja." - - "Oppiaineessa pohditaan ihmis- } \\
\text { kunnan tulevaisuutta ja maailmaa muuttavia kehitys- } \\
\text { kulkuja, kuten uutta mediaympäristöä, teknologian } \\
\text { kehitystä ja ilmastonmuutosta." (s. } 322 \text { ) }\end{array}$ \\
\hline $\begin{array}{l}\text { Minä ja yhteiskunta } \\
\text {-moduuli ( } 2 \text { op) }\end{array}$ & $\begin{array}{l}\text { Keskeisissä sisällöissä: "globaali oikeudenmukaisuus, } \\
\text { kestävä tulevaisuus, ilmastonmuutoksen torjunta sekä } \\
\text { YK:n kestävän kehityksen tavoitteet ja Agenda 2030" } \\
\text { (s. } 324 \text { ) }\end{array}$ \\
\hline \multirow[t]{2}{*}{ Tulevaisuus -moduuli (2 op) } & $\begin{array}{c}\text { Tavoitteissa: "Moduulin tavoitteena on, että opiskelija } \\
\text { - } \text { omaksuu valmiuksia, niin asenteita, tietoja } \\
\text { kuin tunnetaitojakin, kestävän tulevaisuuden } \\
\text { rakentamiseen ja ymmärtää ilmastonmuutok- } \\
\text { sen vaikutuksia sekä sen torjumisen keinoja } \\
\text { ja niiden esteitä" (s. } 327 \text { ) }\end{array}$ \\
\hline & $\begin{array}{l}\text { Keskeisissä sisällöissä: "globaalisti vaikuttavat ekolo- } \\
\text { giset muutokset: ilmastonmuutos, massasukupuutot, } \\
\text { diversiteetin heikkeneminen, kansainvaellukset" } \\
\text { (s. 327) }\end{array}$ \\
\hline
\end{tabular}


Kuten Taulukosta 1 käy ilmi, ilmastonmuutos on liitetty tulevissa lukion opetussuunnitelman perusteissa arvoperustan lisäksi moniin oppiaineisiin. Laaja-alaisen osaamisen osa-alueiksi on määritelty kuusi teemaa, jotka ovat "hyvinvointiosaaminen, vuorovaikutusosaaminen, monitieteinen ja luova osaaminen, yhteiskunnallinen osaaminen, eettisyys ja ympäristöosaaminen sekä globaali- ja kulttuuriosaaminen" (Opetushallitus, 2019, s. 50). Nämä on otettu huomioon kunkin oppiaineen tavoitteiden määrittelyssä, ja samalla on kuvattu, miten laaja-alaisen osaamisen tavoitteet liittyvät oppiaineiden opintoihin. Jatkossa onkin mielenkiintoista nähdä, miten eri oppiaineiden oppimateriaaleissa tullaan huomioimaan esimerkiksi eettisyyteen ja ympäristöosaamiseen sekä ilmastonmuutokseen liittyvät näkökulmat.

Tässä artikkelissa tutkimme suomalaista lukiomaantiedettä ilmastonmuutokseen liittyvän opetuksen näkökulmasta. Koska maantiede on oppiaineena eheyttävä yhdistäessään luonnon- ja ihmistieteellisiä teemoja, se voi tarjota oivalliset mahdollisuudet monipuolisen kokonaiskäsityksen muodostamiseen ilmastonmuutoksen kaltaisesta monimutkaisesta ongelmasta. Tämän vuoksi maantieteen oppiaineen tutkiminen on perusteltua. Kuten olemme edellä todenneet, maantiede on tällä hetkellä voimassa olevassa opetussuunnitelmassa biologian lisäksi ainoa oppiaine, joka huomioi ilmastonmuutoksen. Jatkossa olisi mielenkiintoista tutkia myös biologian tapaa tarkastella ilmastonmuutosta ja myöhemmin, uusimpien opetussuunnitelman perusteiden tullessa voimaan vuonna 2021, myös sitä, kuinka ilmastonmuutoksen opiskelu sisällytetään muihin oppiaineisiin.

Rajaamme tarkastelun lukion maantieteen pakollisen kurssin oppikirjojen analysointiin. Kysymme: 1) Millaista tietoa maantieteen oppikirjat tarjoavat ilmastonmuutoksesta? 2) Millaisia havainnollistamisen keinoja ilmastonmuutoksen käsittelyssä käytetään? 3) Millainen rooli yksilön ja yhteiskunnan vaikutusmahdollisuuksille ilmastonmuutoksen hillinnässä ja sopeutumisessa annetaan?

\section{Aineistot ja menetelmät}

Ilmastonmuutosta käsitellään lukiossa maantieteen ensimmäisellä, toisella ja kolmannella kurssilla. Maantieteen kursseista ainoastaan ensimmäinen on pakollinen kaikille lukio-opiskelijoille. Tällä Maailma muutoksessa -kurssilla ilmastonmuutosta käsitellään sekä luonnon- että ihmismaantieteellisestä näkökulmasta painottaen niin sanotun riskimaantieteen näkökulmia. Toisella maantieteen kurssilla ilmastonmuutosta käsitellään luonnonmaantieteellisenä ilmiönä ja kolmannella kurssilla ihmismaantieteen näkökulmasta.

Tässä artikkelissa keskitymme ensimmäisen maantieteen kurssin ilmastonmuutosta käsitteleviin osuuksiin. Analysoimme kahta lukion maantieteen pakollisen Maailma muutoksessa -kurssin painettua oppikirjaa, jotka noudattavat tällä hetkellä voimassa olevaa, vuoden 2015 lukion opetussuunnitelmaa (Opetushallitus 2015). Ensimmäinen oppikirja on Otavan julkaisemasta Manner-kirjasarjasta (Brander, Hiekka, Paarlahti, Ruth \& Ruth, 2016) ja toinen Sanoma Pron GEOS-sarjasta (Cantell, Jutila, 
Lappalainen \& Sorvali, 2016). Esittelemme ensin tutkimiemme oppikirjojen rakennetta ja teemme yleiskatsauksen niiden sisältöihin. Tämän jälkeen analysoimme tarkemmin ilmastonmuutosta käsittelevät osiot.

Manner-sarjan Maailma muutoksessa -kirjassa on yhdeksäntoista lukua, jotka on ryhmitelty neljään teemaan: "Mitä maantiede on?", "Luonnon ilmiöt", "Ympäristön muutokset" sekä "Maailma muutoksessa". Kirjassa on yhteensä 148 sivua, joissa mukana on 16-sivuinen karttaliite. GEOS-sarjan Maailma muutoksessa -kirja on sivumäärältään melko saman kokoinen Manner-kirjan kanssa: kirjassa on 137 sivua, ja siinäkin on 16-sivuinen karttaliite. GEOS-kirjassa on kaksitoista lukua, joita ei ole erikseen ryhmitelty alateemoihin.

Huolimatta siitä, että molemmat kirjat ovat sivumäärältään melko samankokoisia, niissä käytetyt tekstiä havainnollistavat keinot eroavat toisistaan selvästi: GEOS-kirjassa on käytetty valokuvia huomattavasti enemmän kuin Manner-kirjassa. Myös karttoja ja tietolaatikoita sekä casekuvauksia on GEOS-kirjassa jonkin verran enemmän kuin Mannerkirjassa. Yhteensä Manner-kirjaan sisältyy 303 ja GEOS-kirjaan 401 erilaista leipätekstiä havainnollistavaa elementtiä. Kun tätä havaintoa tarkastellaan kirjojen sivumäärän rinnalla, on helppo todentaa se, mikä käy ilmi jo kirjoja selatessa: Manner-kirjassa leipätekstiä on huomattavasti GEOSkirjaa enemmän.

Olemme tietoisia siitä, kuinka analyysimme ulkopuolelle jättämistämme maantieteen pakollisen kurssin teemoista monet ovat ainakin välillisesti kytköksissä ilmastonmuutokseen, mutta päädyimme keskittämään tarkastelumme kirjojen niihin osiin, joissa ilmastonmuutosta käsitellään eksplisiittisesti. Taulukossa 2 on esitetty ilmastonmuutosta käsittelevien lukujen jäsentely analysoimissamme oppikirjoissa. Manner-kirjassa ilmastonmuutosta käsitellään seitsemänsivuisessa luvussa, jonka otsikkona on "Ilmasto - aina muutoksessa". Luku on jaettu johdantotekstin lisäksi kolmeen alalukuun, joista ensimmäinen käsittelee ilmastonmuutosta hasardina ja toinen ilmaston muuttumisen vaikeaa ennustettavuutta. Kolmannessa alaluvussa esitellään muita ilmastoriskejä: interglasiaalin jälkeen todennäköisesti seuraavaa maapallon ilmaston viilenemistä ja jäätiköitymistä sekä ydin- eli vulkaanisen talven uhkaa. Leipätekstin lukeminen kuitenkin paljastaa, kuinka luvussa on myös neljäs alaluku, joka käsittelee ilmastonmuutoksen torjuntaa ja varautumista (tämän otsikkofontti lienee epähuomiossa muuttunut leipätekstin fontiksi).

GEOS-kirjassa ilmastonmuutosta käsitellään kahdessa luvussa, joista ensimmäinen keskittyy ilmastonmuutoksen syihin ja alueellisiin seurauksiin ja toinen keinoihin, joilla ilmastonmuutokseen pitää varautua ja sopeutua. Ilmastonmuutosta käsitellään yhteensä viidellätoista sivulla. Manner-kirjassa leipätekstiä on selvästi GEOS-kirjaa enemmän, ja ilmastonmuutoslukuja verratessa tämä kirjojen ero tulee esille: huolimatta siitä, että Manner-kirjassa on vain yksi, seitsensivuinen ilmastonmuutosta käsittelevä luku, siinä on aihepiiriin liittyvää leipätekstiä GEOS-kirjaa enemmän. Ilmastonmuutosta käsitellään Manner-kirjassa 1177 sanalla ja 96 virkkeessä, kun GEOS-kirjassa vastaavat luvut ovat 937 ja 90. 
Taulukko 2. Manner-ja GEOS-kirjoissa käytetyt lukujen otsikot ja väliotsikot ilmastonmuutosta käsittelevissä teksteissä.

\begin{tabular}{|c|c|c|c|}
\hline \multicolumn{2}{|c|}{ Manner } & \multicolumn{2}{|c|}{ GEOS } \\
\hline \multirow[t]{7}{*}{$\begin{array}{l}\text { Ilmasto - aina } \\
\text { muutoksessa }\end{array}$} & $\begin{array}{l}\text { Ilmastonmuutos } \\
\text { hasardina }\end{array}$ & \multirow[t]{5}{*}{$\begin{array}{l}\text { Ilmastonmuutoksen } \\
\text { syyt ja alueelliset } \\
\text { seuraukset }\end{array}$} & $\begin{array}{l}\text { Kasvihuoneilmiö } \\
\text { pitää maapallon } \\
\text { lämpimänä }\end{array}$ \\
\hline & $\begin{array}{l}\text { Ilmastonmuutoksen } \\
\text { torjunta ja varautu- } \\
\text { minen }\end{array}$ & & $\begin{array}{l}\text { Kasvihuonekaasu- } \\
\text { jen lisääntyminen } \\
\text { aiheuttaa ilmaston- } \\
\text { muutoksen }\end{array}$ \\
\hline & $\begin{array}{l}\text { Ilmaston muuttu- } \\
\text { mista on vaikea } \\
\text { ennustaa }\end{array}$ & & $\begin{array}{l}\text { Kasvihuonekaasu- } \\
\text { päästöt ovat suuria } \\
\text { rikkaissa maissa ja } \\
\text { Aasiassa }\end{array}$ \\
\hline & Muut ilmastoriskit & & $\begin{array}{l}\text { Ilmastomallit } \\
\text { ennustavat } \\
\text { tulevaisuutta }\end{array}$ \\
\hline & & & $\begin{array}{l}\text { Ilmastonmuutos } \\
\text { näkyy erityisesti } \\
\text { merialueilla }\end{array}$ \\
\hline & & \multirow[t]{2}{*}{$\begin{array}{l}\text { Ilmastonmuutok- } \\
\text { seen pitää varautua } \\
\text { ja sopeutua }\end{array}$} & $\begin{array}{l}\text { Ilmastonmuutok- } \\
\text { seen on pakko } \\
\text { sopeutua }\end{array}$ \\
\hline & & & $\begin{array}{l}\text { Ilmastonmuutok- } \\
\text { sen hillintä vaatii } \\
\text { kansainvälisiä } \\
\text { sopimuksia }\end{array}$ \\
\hline
\end{tabular}

Analysoimme oppikirjojen aineiston teorialähtöisen sisällönanalyysin keinoin. Analysoitavat teemat muodostimme ilmastonmuutokseen liittyvän tutkimuskirjallisuuden perusteella, jotka osittain heijastuvat myös lukion opetussuunnitelman perusteiden tekstissä (Opetushallitus, 2015).

Maantieteen opetussuunnitelmassa pakollisen kurssin keskeiset sisällöt on ryhmitelty neljään teemaan: 1) maantiede tieteenalana, 2) luonnon järjestelmään liittyvät keskeiset globaalit riskialueet, riskien ennakointi ja niihin varautuminen, 3) luonnonvaroihin ja ympäristöön liittyvät keskeiset globaalit riskialueet, riskien hillintä, niihin varautuminen ja sopeutuminen sekä 4) ihmiskunnan globaalit riskialueet ja keskeiset kehityskysymykset (Opetushallitus, 2015, s. 148). Ilmastonmuutoksen opiskelu on liitetty edellä mainittuun kolmanteen teemaan, jonka alla on mainittu "ilmastonmuutokset ja muut globaalit ympäristöriskit, resurssien viisas käyttö sekä kiertotalous ja maapallon eri alueiden mahdollisuudet ja vahvuudet" (Opetushallitus, 2015, s. 148). Kurssin tavoitteiden määrittelyssä edellytetään muun muassa, että opiskelija ymmärtää, millaiset tekijät vaikuttavat eri alueilla esiintyviin riskeihin ja millaisilla keinoilla riskeihin voidaan varautua tai niiden vaikutuksia voidaan hillitä (Opetushallitus, 2015, s. 147).

Aloitimme analyysin muodostamalla teemat, joiden avulla halusimme tarkastella sitä, miten ilmastonmuutokseen liittyvät luonnontieteelliset ja ihmistieteelliset näkökulmat on tuotu esiin. Kuten aiemmissa tutkimuksissa on todettu, ilmastonmuutoksen ymmärtäminen edellyttää 
riittävää tietoa ilmiöön vaikuttavista prosesseista (esim. Ratinen, 2016). Pelkkä tieto ei kuitenkaan riitä, vaan sen rinnalla tarvitaan myös sen ymmärtämistä, että ihmiset - sekä yhteiskunnan että yksilöiden tasolla voivat vaikuttaa ilmastonmuutoksen hillintään ja siihen sopeutumiseen (Aarnio-Linnanvuori ym., 2018). Näihin näkökulmiin tukeutuen muodostimme seuraavat kuusi teemaa:

1. Ilmastonmuutoksen luonnolliset syntymekanismit

2. Ilmastonmuutoksen vaikutus ympäristöön

3. Ihmisen vaikutus ilmastonmuutokseen

4. Luonnon ja ihmisen yhteisvaikutus ilmastonmuutokseen

5. Ilmastonmuutoksen hillintä- ja sopeutumiskeinot yksilötasolla

6. Ilmastonmuutoksen hillintä- ja sopeutumiskeinot yhteiskunnan tasolla

Teimme ilmastonmuutosta käsittelevien lukujen analyysin virketasolla niin, että kunkin virkkeen pääasiallisin sisältö määritti sen, mihin teemaan virke laskettiin. Kukin virke sijoitettiin siis ainoastaan yhteen kuudesta teemasta. Neljäs teema eli luonnon ja ihmisen yhteisvaikutus ilmastonmuutokseen otettiin omaksi teemakseen, koska jotkin ilmastonmuutosta voimistavista tekijöistä oli vaikea eritellä joko luonnollisiin syntymekanismeihin tai puhtaasti ihmisen aiheuttamiin vaikutuksiin. Jotkin virkkeet eivät myöskään viitanneet suoraan ilmastonmuutokseen vaikuttaviin tekijöihin, vaan liittyivät epäsuorasti joko luonnonmaantieteelliseen tai ihmismaantieteelliseen näkökulmaan tai näiden keskinäiseen suhteeseen. Virkkeen pääasiallista näkökulmaa käytettiin näissä tapauksissa luokitteluperusteena.

Ensimmäisellä analyysikierroksella keskityimme ainoastaan leipätekstin virkkeiden luokitteluun. Sen jälkeen tarkensimme analyysia ottamalla mukaan GEOS-kirjassa tärkeässä asemassa olevat case-kuvaukset. Tähän ratkaisuun päädyttiin, koska pelkkä leipätekstin analysointi antoi GEOS-kirjan ilmastonmuutoskappaleiden sisällöstä vääristyneen kuvan. Analysoimme myös sitä, millaisia havainnollistamiskeinoja kirjoissa oli käytetty. Kirjojen tehtävien lukumäärän otimme huomioon, mutta emme niiden sisältämiä havainnollistuksia.

Esittelemme seuraavaksi analyysimme tulokset edellä esitetyn luokittelun perusteella, minkä jälkeen tarkastelemme tuloksia peilaamalla niitä ilmastokasvatuksen polkupyörämallin jäsentelyyn.

\section{Tulokset}

\section{Millaista tietoa ilmastonmuutoksesta kirjat sisältävät?}

Analysoimiemme kirjojen tekstit eroavat laajuudeltaan, sisällöltään, tyyliltään ja jäsentelytavaltaan toisistaan selvästi. Manner-kirjassa avainkäsitteet on joko alleviivattu, jolloin käsite on selitetty samalla aukeamalla sivun alalaidassa, tai lihavoitu, jolloin käsite on selitetty heti tekstin yhteydessä. GEOS-kirjassa avainkäsitteet on lihavoitu ja ne on selitetty kirjan lopussa olevassa käsiteluettelossa tai tekstin oheen liitetyissä tekstilaatikoissa. Molempien kirjojen avainkäsitteet on koottu taulukkoon 3. 
Ainoastaan kolme avainkäsitettä (kasvihuoneilmiö, kasvihuonekaasut ja IPCC) esiintyy molemmissa kirjoissa ilmastonmuutoksen yhteydessä niin, että niiden merkitys on eksplisiittisesti selitetty joko leipätekstissä tai erillisenä käsitteen määrittelynä.

Taulukko 3. Ilmastonmuutokseen liitetyt avainkäsitteet Manner-ja GEOSkirjoissa.

\begin{tabular}{|l|l|}
\hline \multicolumn{1}{|c|}{ Manner } & \multicolumn{1}{c|}{ GEOS } \\
\hline kasvihuoneilmiö & kasvihuoneilmiö \\
\hline kasvihuonekaasut & kasvihuonekaasut \\
\hline IPCC & IPCC \\
\hline hiilijalanjälki & hiilinielu \\
\hline interglasiaalijakso & hillintä \\
\hline orgaaninen aines & ilmastomalli \\
\hline palautemekanismi & ilmastonmuutos \\
\hline Pariisin sopimus & skenaario \\
\hline orgaaninen & sopeutuminen \\
\hline
\end{tabular}

Kasvihuoneilmiön periaate selitetään molemmissa kirjoissa sekä tekstin että asiaa havainnollistavan piirroskuvan avulla. Molemmissa kirjoissa kerrotaan ihmisen vaikutuksesta kasvihuonekaasujen lisääntymiseen. Tämän lisäksi kasvihuonekaasujen merkitys pitkäaaltoisen säteilyn poistumisen hidastajana mainitaan. Jonkin verran kirjoissa on eroa siinä, mitä kasvihuonekaasuja mainitaan: molemmat kirjat luettelevat vesihöyryn, hiilidioksidin, metaanin ja dityppioksidin kasvihuonekaasuiksi. Näiden lisäksi GEOS-kirjassa kasvihuonekaasuiksi mainitaan alailmakehän otsoni sekä CFC-yhdisteet (GEOS, s. 59). Manner-kirjassa CFC-yhdisteistä ei puhuta tällä nimellä, mutta erikseen mainitaan CFC-12 ja HCFC-22, ja näiden lisäksi kasvihuonekaasuina mainitaan hiilivedyt, bromiyhdisteet, perfluorometaani sekä rikkiheksafluoridi (Manner, s. 61).

Molempien kirjojen kautta välittyy ymmärrys siitä, että ihmistoiminnan voimistama kasvihuonekaasujen lisääntyminen ilmakehässä aiheuttaa ilmastonmuutoksen. GEOS-kirjassa (s. 60) todetaan, kuinka sadan viime vuoden aikana ihmisen toiminta on ollut suurin maapallon lämpötilan kohoamisen aiheuttaja, kun Manner-kirjassa (s. 60) puhutaan 150 vuodesta. Tässä yhteydessä on aiheellista pitää mielessä, kuinka esimerkiksi vuonna 2018 julkaistussa IPCC-raportissa vertailukohtana pidetään maapallon keskilämpötilaa 1800-luvun loppupuolella, ennen teollisen vallankumouksen kiihtymistä. Huolimatta siitä, että ilmastonmuutoksen perusmekanismi on selitetty molemmissa kirjoissa selkeästi, ilmiöön liittyvissä tarkemmissa tiedoissa on jonkin verran eroja.

Kuvissa 1 ja 2 on esitetty ilmastonmuutokseen liittyvien tekstien pääasialliset sisällöt. Analyysimme perusteella kirjat painottavat ilmastonmuutokseen liittyviä teemoja hyvin eri tavalla: Manner-kirjassa suurin osa tekstistä keskittyy ilmastonmuutoksen syntyyn liittyvien mekanismien kuvaukseen sekä siihen, millaisia vaikutuksia ilmastonmuutoksella on 


\section{Ainedidaktiikka 4(2) (2020)}

ympäristöön. Erityisen vahvasti kirjassa painotetaan ilmastonmuutoksen ympäristövaikutuksia (41 prosenttia tekstistä): valtamerten pinnan nousua, meriveden happamoitumista, korallien tuhoutumista, kalakantojen romahtamista, sään ääri-ilmiöiden yleistymistä, eläin- ja kasvilajien sukupuuton uhkaa, viljelymahdollisuuksien muutoksia ja terveydellisten ongelmien lisääntymistä. Näitä samoja teemoja käsitellään myös GEOS-kirjassa, mutta niiden suhteellinen osuus koko tekstistä on selvästi pienempi (24 prosenttia). Ihmisen vaikutusta sekä ihmisen ja luonnon yhteisvaikutusta ilmastonmuutokseen käsitellään molemmissa kirjoissa suhteessa koko tekstiin yhtä paljon, 15 prosentissa koko tekstistä.

Kuva 1. Ilmastonmuutosta käsittelevien tekstien teemat Manner GE1 -kirjassa.

\section{Ilmastonmuutokseen liittyvät tekstit Manner GE1 -kirjassa}

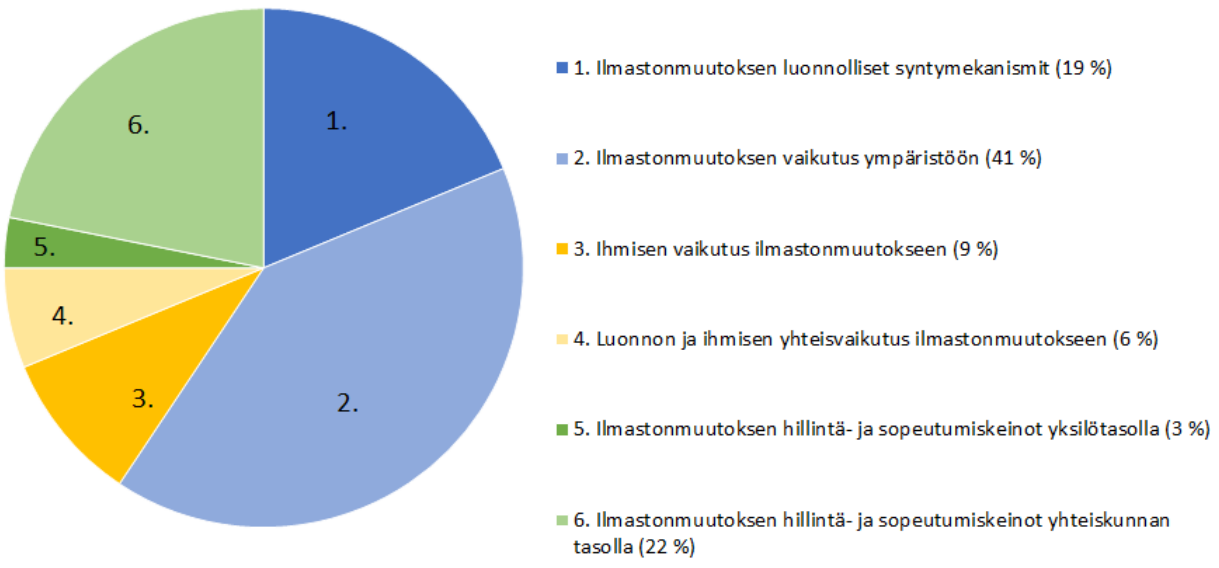

Kuva 2. Ilmastonmuutosta käsittelevien tekstien teemat GEOS 1 -kirjassa.

Ilmastonmuutokseen liittyvät tekstit GEOS 1-kirjassa

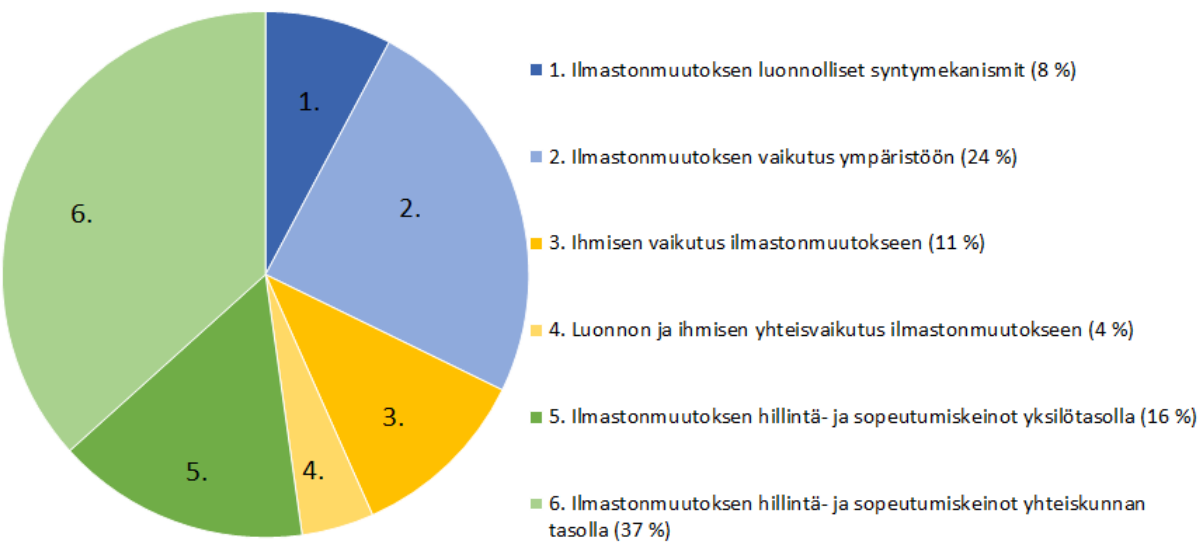




\section{Millaisia havainnollistamisen keinoja kirjoissa käytetään?}

Kirjojen ilmastonmuutosta käsittelevissä luvuissa leipätekstiä havainnollistavien elementtien lukumäärässä on huomattava ero: Manner-kirjassa näitä oli yhdeksän ja GEOS-kirjassa 51 kappaletta (kuva 3). Tehtävien määrässä oli myös selvä ero: Manner-kirjassa ilmastonmuutosta käsiteltiin neljässä ja GEOS-kirjassa kahdessatoista tehtävässä. GEOS-kirjassa ilmastonmuutoksen opiskelussa korostuvatkin suhteellisen lyhyiden tekstikappaleiden rinnalle liitetyt muut elementit: valokuvia on erittäin paljon, ja niiden lisäksi myös tietolaatikoita, case-kuvauksia ja diagrammeja on käytetty huomattavasti enemmän kuin Manner-kirjan ilmastonmuutosluvun yhteydessä. On kiinnostavaa huomata, että Manner-kirjassa ilmastonmuutoksen käsittelyyn ei ole liitetty yhtään karttaa. GEOS-kirjan valokuvissa on kuvattu ympäristöjä, joihin ilmastonmuutos vaikuttaa: kuivuudesta kärsivää laidunmaata, merialueen tornadoa, metsäpaloa, mangrovemetsää, saaria sekä kaupunkialuetta, joka kärsii merenpinnan kohoamisesta. Kuvat pakolaisleiristä ja nälänhädästä kärsivästä lapsesta tuovat ilmastonmuutoksen vaikutukset lähelle yksittäisten ihmisten kokemuksia.

Kuva 3. Ilmastonmuutoksen käsittelyyn liittyvät havainnollistamisen keinot (kpl) Manner- ja GEOS-sarjojen Maailma muutoksessa -kurssin kirjoissa.

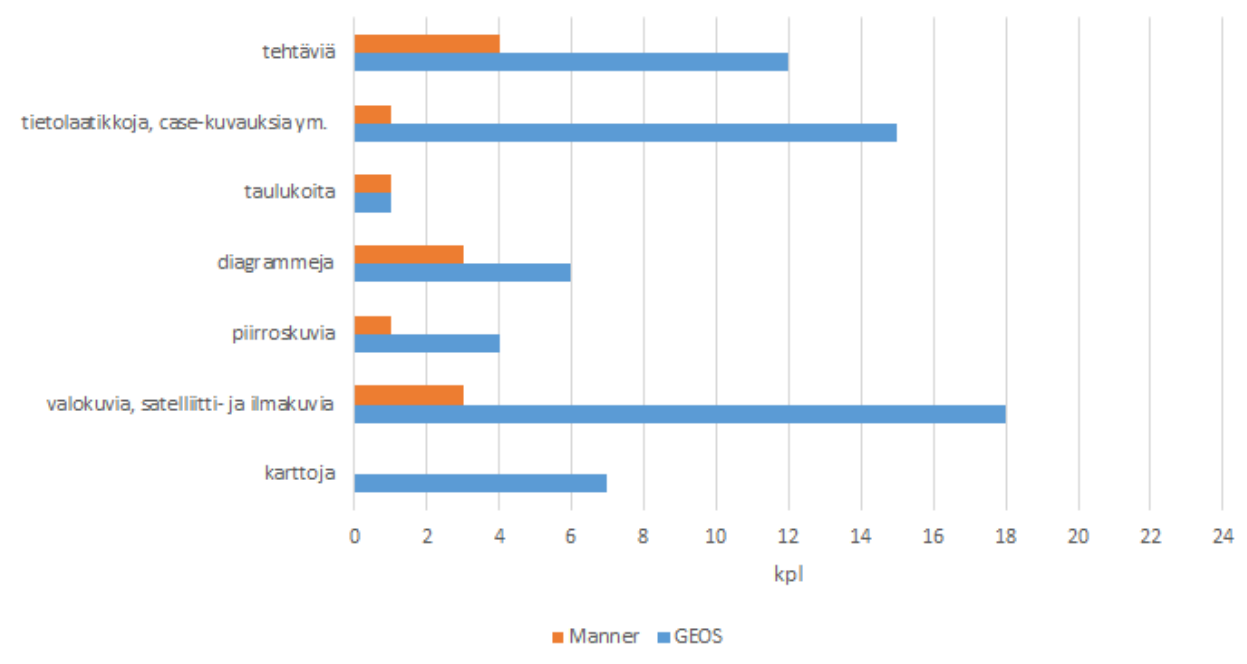

Ilmastonmuutokseen liittyvien uhkia ja ongelmia korostavien kuvien rinnalle GEOS-kirja tuo myös monia esimerkkejä siitä, kuinka ilmastonmuutokseen voidaan reagoida joko varautumalla tuleviin muutoksiin tai pyrkimällä vaikuttamaan ilmastonmuutoksen hillintään. Kuvissa on aurinkopaneeleja, viherkattoja, puunistutusta, sähköpyöriä, elektroniikkajätteen kierrätystä, sään ääri-ilmiöitä kestäviä taloja sekä ilmastonmuutosta vastustavaan mielenosoitukseen osallistujia (kuva 4a). Sitä vastoin Manner-kirjan kuvitus noudattaa hyvin erilaista linjaa: valokuvia on ainoastaan yksi kuvapari sveitsiläisen jäätikön sulamisesta vuosien 1994 ja 2006 välillä. Ilmaston lämpenemisen vaikutuksia on esitetty diagrammissa (kuva 4b). Tämän lisäksi ilmastonmuutostekstin yhteydessä on yksi ilmakuva Malediivien saaristosta, jota merenpinnan kohoaminen uhkaa. 
Kuvat 4a ja 4b. Esimerkit GEOS-ja Manner-kirjojen havainnollistuksista. Vasemmalla osa GEOS-kirjan (s. 69) kuvasta "mielenilmaus ilmastonmuutosta vastaan" (Mark Boulton, Mary Evans Picture Library / Lehtikuva) ja oikealla osa Manner-kirjan (s. 64) kuvasta "ilmaston lämpenemisen vaikutuksia" (Jonatan Hildén, Juuso Kuponen \& Katri Tikkanen / Kirstu).
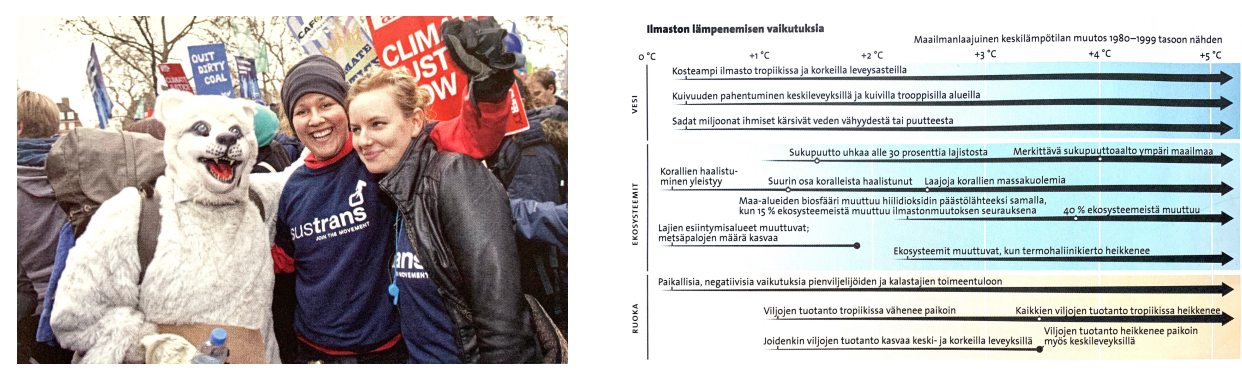

\section{Millainen rooli yksilölle ja yhteiskunnalle kirjoissa annetaan?}

Analysoidut oppikirjat eroavat toisistaan selvästi sen suhteen, millainen painoarvo ilmastonmuutoksen hillintään ja sopeutumiseen liittyville keinoille tekstissä annetaan: Manner-kirjassa neljäsosa (25 prosenttia) tekstistä esittelee keinoja, joilla ilmastonmuutosta voidaan hidastaa tai joilla siihen voi sopeutua. Laajimmin kirja kertoo kansainvälisistä ilmastosopimuksista ja niiden tavoitteista. Tekstistä ainoastaan kolme prosenttia liittyy yksilön vaikutusmahdollisuuksiin:

Ilmastonmuutosta voi kukin hillitä omilla toimillaan. Energian säästäminen, ilmastomyönteiset ruokavalinnat, kuten kasvikset ja lähiruoka, sekä lentokonematkustamisen välttäminen ovat keinoja vähentää omaa hiilijalanjälkeään eli käyttämistään tuotteista ja palveluista koituvia kasvihuonekaasujen päästöjä. Ilmaston-muutokseen voi vaikuttaa myös omassa kunnassa tai kaupungissa. (Manner, s. 63)

GEOS-kirjassa yksilön ja yhteiskunnan vaikutusmahdollisuuksia käsitellään sen sijaan laajasti: 37 prosenttia tekstistä käsittelee ilmastonmuutoksen hillintä- ja sopeutumiskeinoja yhteiskunnan ja 16 prosenttia yksilötasolla. Ilmastosopimusten lisäksi kirjassa kerrotaan muista yhteiskunnan toimista, joilla ilmastonmuutosta voidaan hillitä. Kirjassa luetellaan energiaan, maa- ja metsätalouteen, rakentamiseen, liikenteeseen sekä teollisuuteen liittyviä keinoja, joilla ilmastonmuutosta voidaan hidastaa. Yksilötason vaikutusmahdollisuuksia on kuvattu kahden esimerkkitapauksen avulla, joista ensimmäinen on 16-vuotiaan tytön haastattelu, jossa hän kertoo omasta ilmastoherätyksestään ja toiminnastaan:

Omassa elämässäni olen tiivistänyt vaikutuskeinot neljään pääasiaan, jotka pystyn tekemään ilman suuria uhrauksia: liikun paljon polkupyörällä, ostan aina välillä käytettyjä vaatteita, vältän ruuan poisheittämistä ja tietysti kierrätän jätteet. Laskin netissä oman hiilijalanjälkeni ja havaitsin, että jo näillä teoilla on yllättävän suuri vaikutus. (GEOS, s. 71) 
Ainedidaktiikka 4(2) (2020)

Toisena esimerkkinä kirja kertoo espoolaisesta perheestä, joka oli päättänyt vaikuttaa omakotitalonsa energian käyttöön asentamalla talonsa katolle aurinkopaneelit:

Aurinkopaneelien asennus oli todella helppoa. Ja sähköä syntyy kuin itsestään. Tuntuu todella mukavalta, kun saamme energiaa suoraan Auringosta ja voimme näin vaikuttaa ilmastoasioihin, perheen äiti Kirsi Ripatti kertoo. (GEOS, s. 71)

Yhteenvetona voidaan todeta, että analysoimamme oppikirjat muodostavat keskenään hyvin erilaisen kuvan siitä, millaisia ilmastonmuutoksen hillitsemisen ja sopeutumisen keinoja on olemassa. Molemmat kirjat tuovat yhteiskunnallisen tason vaikuttamisen esiin erityisesti kertoessaan kansainvälisten ilmastosopimusten tärkeydestä. Sen sijaan yksilön vaikutusmahdollisuuksista kerrotaan melko niukasti.

\section{Pohdinta}

Tässä artikkelissa olemme tutkineet, millaista käsitystä ilmastonmuutoksesta lukion pakollisen maantieteen Maailma muutoksessa -kurssin kaksi vaihtoehtoista oppikirjaa (GEOS ja Manner) välittävät. Teorialähtöisen sisällönanalyysimme tasapuolisuutta lisäsi se, että GEOS- ja Mannerkirjojen ilmastonmuutosta käsittelevät luvut ovat virkkeiden lukumääriltään lähes yhtä pitkät.

Lukion opetussuunnitelman perusteet (Opetushallitus, 2015) määrittelevät maantieteen opetuksen tavoitteiden ja sisältöjen päälinjat. Ilmastonmuutoksen osalta lukion opetussuunnitelma painottaa arvoperustaa ja kestävän elämäntavan ylläpitämistä ilmastonmuutoksen hillitsemiseksi. Opetussuunnitelman tavoitteiden mukaisesti opiskelijan tulee ymmärtää ilmastonmuutokseen vaikuttavia tekijöitä ja ihmisen toiminnan merkitystä ilmastonmuutosta kiihdyttävänä voimana. Sekä GEOS- että Manner-oppikirja käsittelevät ilmastonmuutoksen syntytapoja, kiihdyttäviä tekijöitä ja sen vaikutuksia ympäristölle asiantuntevasti. Sen sijaan Meehan ja muut (2018) ovat havainneet näissä seikoissa puutteita yhdysvaltalaisissa maantieteen oppikirjoissa. Kummassakaan analysoimassamme oppikirjassa ei myöskään kyseenalaisteta ilmastonmuutoksen todenperäisyyttä (vrt. Romàn \& Busch, 2016).

Vaikka kummankin oppikirjan päälinjat seuraavat melko pitävästi lukion opetussuunnitelman perusteita (2015), oppikirjojen välillä on havaittavissa eroja. Opetussuunnitelma painottaa esimerkiksi ihmisen toiminnan vaikutusta ilmastonmuutosta kiihdyttävänä tekijänä, mutta sekä GEOS- että Manner-kirja käsittelevät tätä vain noin kymmenen prosenttia koko tekstistä. Ihmisen toiminnan seurauksena lisääntyneitä päästöjä ilmastonmuutoksen voimistumisen keskeisimpänä tekijänä painotetaan myös IPCC:n (2018) raportissa. Oppikirjat käsittelevät vahvimmin ilmastonmuutoksen vaikutusta ympäristölle, jota lukion opetussuunnitelman tavoitteissa ei kuitenkaan ole nostettu esiin yhtä selkeästi kuin muita teemoja. Toisaalta ympäristövaikutusten ymmärtäminen ja sisäistäminen voivat osallistaa ja sitouttaa yksilön ilmastonmuutoksen hillitsemiseen, kun ilmiön konkreettiset seuraukset ovat tiedossa. 
Kun Manner-kirjassa suurin huomio keskittyy ilmastonmuutoksen ympäristövaikutuksiin, GEOS-kirjassa päähuomio painottuu ilmastonmuutoksen hillintä- ja sopeutumiskeinoihin sekä yhteiskunnan että yksilön tasolla. GEOS-kirjassa painotetaan Manner-kirjaa vahvemmin ratkaisukeskeisyyttä kuin ilmiön seurausten erittelyä. Kuten kokonaisvaltaisessa ilmastokasvatuksen polkupyörämallissa esitetään, vaikuttamisen mahdollisuudet ovat yksi tärkeimmistä ilmastonmuutokseen liittyvistä teemoista (Tolppanen ym., 2017). Mallin satula eli motivaation ja osallisuuden lisääminen sekä polkimet eli toimintaan kannustaminen korostavat teeman tärkeyttä ilmastokasvatuksessa. Näitä osia painotetaan myös lukion opetussuunnitelman perusteissa (Opetushallitus, 2015).

Tutkimuksemme tulokset kuitenkin osoittavat, että painotus molemmissa oppikirjoissa on vahvemmin yhteiskunnan tason hillitsemis- ja sopeutumiskeinoissa. Myös Salonen ja Hakari (2018, s. 94) esittävät, että koko yhteiskunnan tasolla toteutettava interventio olisi tehokkaampi tapa saavuttaa kestävyysmuutos kuin pyrkimällä muuttamaan yksittäisen ihmisen asenteita ja käyttäytymistä. Tällöin ihminen nähdään kuitenkin lähinnä objektin, eikä aktiivisen vaikuttajan roolissa.

Tulostemme mukaan yksilötason keinoja ei nosteta esiin kummassakaan oppikirjassa kovinkaan paljon. Nuorten tulisikin sisäistää ja ymmärtää yksilötason helposti toteutettavia ilmastonmuutoksen hillitsemisen keinoja. Oppikirjat eivät tarjoa tähän teemaan juurikaan työkaluja, mikä onkin molempien oppikirjojen yksi suurimmista puutteista opetussuunnitelman tavoitteiden näkökulmasta. Vuoden 2018 jälkeen esiin noussut keskustelu ilmastoahdistuksesta ja positiivisten ilmastouutisten käsittelyn tärkeydestä vastapainoksi uhkakuville vaikuttaa toivoaksemme tulevien oppimateriaalien sisältöihin ja käsittelytapoihin.

Myös O’Brien (2018, ss. 155-156) korostaa yksilön mahdollisuuksia vaikuttaa ilmastonmuutoksen hillintään ja sopeutumiseen, sillä niin poliittiset uudistukset kuin käytännölliset ratkaisutkaan eivät hänestä ole mahdollisia ilman, että ne suodatetaan ja hyväksytään yksilötasolla. Yksilön valinnat vaikuttavat esimerkiksi siihen, miten pyöräilyn ja kasvisruoan määrää voidaan lisätä ja siihen, millä tavoilla luonnonvaroja kulutetaan nyt ja tulevaisuudessa. Ilmastonmuutosta ei myöskään ratkaista vain teknologisten ratkaisujen avulla, vaan jokaisen yksilön tulee muuttaa omaa arvomaailmaansa, maailmankuvaansa ja ajattelutapojaan. Värrin $(2018$, s. 111) mukaan toivo ilmastonmuutoksen suhteen piilee nimenomaan siinä, että luovumme väärästä toivosta eli siitä, että kaikki ympäristöongelmat on ratkaistavissa teknologian avulla. Teknologian sijaan Värri $(2018$, s. 123) peräänkuuluttaa eettistä ja ekologista kuvittelukykyä, jolla hän viittaa yksilön empatiakyvyn kehittymiseen ja omantunnon herkistymiseen. Siihen liittyvät myös yksilön arvostelukyvyn kehittyminen, toivoa luovien maailmojen kuvitteleminen sekä kyky kauneuden kokemiseen (Värri, 2018, s. 137). Ekologisen kuvittelukyvyn myötä kasvatus uuteen, nykyistä viisaampaan luontosuhteeseen on mahdollista.

Lehtosen ja muiden (2018, ss. 364-365) mukaan ilmastokasvatuksen tavoitteena on kasvattaa yksilöitä, jotka kykenevät suhtautumaan kriittisesti ja reflektiivisesti globaaleista ilmiöistä saatavilla olevaan moninaiseen tietoon. Ilmastokasvatus edellyttää kriittistä ajattelua kuluttajuudesta sekä globalisaation, kapitalismin ja mainonnan keinoista tuottaa ihmisille 


\section{Ainedidaktiikka 4(2) (2020)}

onnea: Mitä hyvinvointi meille tarkoittaa? Millaiseen hyvinvoinnin tasoon olemme tyytyväisiä? Miten kestävyys ilmenee käytännön toimissamme? Kokonaisvaltaisen ilmastokasvatuksen polkupyörämallin runko kannustaa pohtimaan näitä arvoihin, maailmankuvaan ja identiteettiin liittyviä kysymyksiä. Lukiossa niitä voidaan pohtia esimerkiksi oppiainerajat ylittävissä teemaopinnoissa. Opiskelijalähtöisessä lähestymistavassa korostetaan tutkivaa ja ongelmakeskeistä oppimista sekä ilmastonmuutoksen merkityksellisyyttä opiskelijan itsensä kannalta (Kokkonen \& Laherto, 2018, s. 26). Myös maantieteen oppikirjojen tulisi antaa monipuolisia esimerkkejä vaikuttavista ja merkityksellisistä ilmastoteoista, jotka vahvistavat lukiolaisten tulevaisuustoivoa. Edellä mainittujen kysymysten pohtiminen on tärkeää, sillä kuten GEOS-kirjassa (s. 68) todetaan, "ilmastonmuutokseen on pakko sopeutua".

\section{Lähteet}

Aarnio-Linnanvuori, E. (2018). Ympäristö ylittää oppiainerajat: arvolatautuneisuus ja monialaisuus koulun ympäristöopetuksen haasteina. (Väitöskirja). Helsingin yliopisto. http://urn.fi/URN:ISBN:978-951-51-3836-1

Aarnio-Linnanvuori, E., Cantell, H., Lehtonen, A. \& Tolppanen, S. (2018). Polkupyörämalli ilmastokasvatuksen tueksi. Ympäristökasvatus 3. https://feesuomi.fi/lehti/polkupyoramalli-ilmastokasvatuksen-tueksi/

Bagoly-Simó, P. (2013). Half-told stories of climate change: School geography and (un)sustainable development. Geography, 98(3), 123-132.

Bagoly-Simó, P. (2014). International differences in the presentation of climate (change) in geography textbooks. Teoksessa D. Schmeinck \& J. Lidstone (toim.), Standards and research in geography education: Current trends and international issues (ss. 125-134). Berlin: Deutsche Nationalbibliothek.

Brander, N., Hiekka, S., Paarlahti, A., Ruth, C. \& Ruth, O. (2016). Manner 1: Maailma muutoksessa. Helsinki: Otava.

Cantell, H. (2014). Ympäristöoppi: Ensi askel tieteiden integraatioon. Teoksessa H. Ruuska, M. Löytönen \& A. Rutanen (toim.), Laatua! Oppimateriaalit muuttuvassa tietoympäristössä (ss. 81-89). Helsinki: Suomen Tietokirjailijat.

Cantell, H. (2015). Ainejakoisuus ja monialainen eheyttäminen opetuksessa. Teoksessa H. Cantell (toim.), Näin rakennat monialaisia oppimiskokonaisuuksia (ss. 11-15). Jyväskylä: PS-kustannus.

Cantell, H., Jutila, H., Lappalainen, S. \& Sorvali, M. (2016). GEOS 1: Maailma muutoksessa. Helsinki: Sanoma Pro.

Cantell, H., Tolppanen, S., Aarnio-Linnanvuori, E. \& Lehtonen, A. (2019). Bicycle model on climate change education: Presenting and evaluating a model. Environmental Education Research, 25(5), 717-731. https://doi.org/10.1080/13504622.2019.1570487

Crouch, D. (2018). The Swedish 15-year-old who's cutting class to fight the climate crisis. The Guardian 1.9.2018. https://www.theguardian.com/science/2018/sep/01/swedish-15-year-old-cutting-class-to-fight-the-climate-crisis

Gessen, M. (2018). The fifteen-year-old climate activist who is demanding a new kind of politics. The New Yorker 2.10.2018. https://www.newyorker.com/news/our-columnists/the-fifteen-year-old-climate-activist-who-is-demanding-a-new-kind-ofpolitics

Hermans, M. (2016). Geography teachers and climate change: Emotions about consequences, coping strategies, and views on mitigation. International Journal of Environmental and Science Education, 11(4), 389-408.

Hiidenmaa, P. (2014). Oppikirjojen tutkimus. Teoksessa H. Ruuska, M. Löytönen \& A. Rutanen (toim.), Laatua! Oppimateriaalit muuttuvassa tietoympäristössä (ss. 27-40). Helsinki: Suomen Tietokirjailijat.

Ikonen, P. (2009). Ilmastonmuutos lukiomaantieteen oppikirjoissa 1954-2005. Natura, 46(3), 52-59. 


\section{Ainedidaktiikka 4(2) (2020)}

IPCC (2018). Global warming of $1,5^{\circ} \mathrm{C}$. Special report. The Intergovernmental Panel on Climate Change. https://www.ipcc.ch/sr15/

Juuti, K., Kairavuori, S. \& Tani, S. (2015). Tiedonalalähtöinen eheyttäminen. Teoksessa H. Cantell (toim.), Näin rakennat monialaisia oppimiskokonaisuuksia (ss. 77-93). Jyväskylä: PS-kustannus.

Kansalaisaloite (2019). Ilmasto-oppi uudeksi oppiaineeksi. 18.3.2019. VN/1542/2019. https://www.kansalaisaloite.fi/fi/aloite/3923

Kokkonen, T. \& Laherto, A. (2018). Tiedeopetuksen muuttuvat tavoitteet: sisältötiedosta luonnontieteelliseen lukutaitoon. Ainedidaktiikka, 2(1), 20-38. https://doi.org/10.23988/ad.69250

Lehtonen, A. \& Cantell, H. (2015). Ilmastokasvatus osaamisen ja vastuullisen kansalaisuuden perustana. Suomen Ilmastopaneeli, Raportti 1/2015. https://www.ilmastopaneeli.fi/wp-content/uploads/2018/10/Ilmastokasvatuksen-raportti9.6.2015.pdf

Lonka, K. (2018). Phenomenal learning from Finland. Helsinki: Edita.

Meehan, C. R., Levy, B. L. M. \& Collet-Gildard, L. (2018). Global climate change in U.S. high school curricula: Portrayals of the causes, consequences, and potential responses. Science Education, 102(3), 498-528. https://doi.org/10.1002/sce.21338

Mochizuki, Y. \& Bryan, A. (2015). Climate change education in the context of education for sustainable development: rationale and principles. Journal of Education for Sustainable Development, 9(1), 4-26. https://doi.org/10.1177/0973408215569109

Niemelä, M. A. \& Tirri, K. (2018). Teachers' knowledge of curriculum integration: a current challenge for Finnish subject teachers. Teoksessa Y. Weinberger \& Z. Libman (toim.), Contemporary pedagogies in teacher education and development (ss. 119-132). London: IntechOpen. https://doi.org/10.5772/intechopen.75870

O'Brien, K. (2018). Is the $1.5^{\circ} \mathrm{C}$ target possible? Exploring the three spheres of transformation. Current Opinion in Environmental Sustainability, 31, 153-160. https://doi.org/10.1016/j.cosust.2018.04.010

Opetushallitus (2003). Lukion opetussuunnitelman perusteet. Helsinki: Opetushallitus.

Opetushallitus (2004). Perusopetuksen opetussuunnitelman perusteet. Helsinki: Opetushallitus.

Opetushallitus (2014). Perusopetuksen opetussuunnitelman perusteet. Helsinki: Opetushallitus.

Opetushallitus (2015). Lukion opetussuunnitelman perusteet. Helsinki: Opetushallitus.

Opetushallitus (2019). Lukion opetussuunnitelman perusteet 2019. Helsinki: Opetushallitus.

Pekkarinen, E. \& Myllyniemi, S. (toim.) (2019). Vaikutusvaltaa Euroopan laidalla: Nuorisobarometri 2018. Helsinki: Valtion nuorisoneuvosto, Nuorisotutkimusseura, Nuorisotutkimusverkosto \& Opetus- ja kulttuuriministeriö. https://tietoanuorista.fi/wp-content/uploads/2019/03/NB 2018 web.pdf

Pihkala, P. (2017). Kuinka käsitellä maailman ongelmia? Traagisuus ja toivo ympäristökasvatuksessa. Ainedidaktiikka, 1(1), 2-15. https://doi.org/10.23988/ad.v1i1.65801

Pihkala, P. (2018). Eco-anxiety, tragedy, and hope: Psychological and spiritual dimensions of climate change. Zygon, 53(2), 545-569. https://doi.org/10.1111/zygo.12407

Piispa, M. \& Myllyniemi, S. (2019). Nuoret ja ilmastonmuutos: tiedot, huoli ja toiminta Nuorisobarometrien valossa. Yhteiskuntapolitiikka, 84(1), 61-69. http://urn.fi/URN:NBN:fi-fe201902144980

Ratinen, I. (2016). Primary student teachers' climate change conceptualization and implementation on inquiry-based and communicative science teaching: a design research. (Väitöskirja). Jyväskylän yliopisto. http://urn.fi/URN:ISBN:978-951-39-6667-6

Ratinen, I., Kinni, A., Muotka, A. \& Sarivaara, E. (2019). Kohti ratkaisukeskeistä ilmastokasvatusta. Suomen Ilmastopaneeli, Raportti 9/2019. https://www.ilmastopaneeli.fi/wp-content/uploads/2019/11/Ilmastokasvatusraportti final.pdf

Ratinen, I. \& Uusiautti, S. (2020). Finnish students' knowledge of climate change mitigation and its connection to hope. Sustainability, 12(6), 2181. https://doi.org/10.3390/su12062181 


\section{Ainedidaktiikka 4(2) (2020)}

Ratinen, I. \& Vettenranta, J. (2018). Oppilaiden ilmastonmuutososaamisen suhde heidän käsityksiinsä omasta ympäristötietoisuudesta ja -optimismista. Teoksessa J. Rautopuro \& K. Juuti (toim.), PISA pintaa syvemmältä: PISA 2015 Suomen pääraportti (ss. 153-173). Kasvatusalan tutkimuksia 77. Jyväskylä: Suomen Kasvatustieteellinen Seura.

Ratinen, I., Viiri, J. \& Lehesvuori, S. (2013). Primary school student teachers' understanding of climate change: comparing the results given by concept maps and communication analysis. Research in Science Education, 43(5), 1801-1823. https://doi.org/10.1007/s11165-012-9329-7

Rimaila, E. (2019). Koko maailman ilmastolakko. Helsingin Sanomat 15.3.2019. https:/www.hs.fi/ulkomaat/art-2000006036750.html

Rinne, E. (2019). (Moni)kulttuurinen maailmankuva ja kuulumisen politiikka suomalaisissa peruskoulun oppikirjoissa ja nuorten kokemuksissa. (Väitöskirja). Tampereen yliopisto. http://urn.fi/URN:ISBN:978-952-03-1182-7

Román, D. \& Busch, K. C. (2016). Textbooks of doubt: using systemic functional analysis to explore the framing of climate change in middle-school science textbooks. Environmental Education Research, 22(8), 1158-1180. https://doi.org/10.1080/13504622.2015.1091878

Salonen, A. O. \& Hakari, S. (2018). Early childhood educators and sustainability: sustainable living and its materialising in everyday life. Utbildning \& Demokrati, 27(2), 81-102.

https:/www.oru.se/globalassets/oru-sv/forskning/forskningsmiljoer/hs/humus/utbildning-och-demokrati/2018/nr-2/arto-o.-salonen--sylvia-hakari---earlychildhood-educators-and-sustainability.pdf

Tani, S. (2017). Maantieteen opetuksen haasteita: digitalisaatio, opetuksen eheyttäminen ja opettajan roolin murros. Terra - Maantieteellinen aikakauskirja, 129(4), 211222.

Tolppanen, S., Aarnio-Linnanvuori, E., Cantell, H. \& Lehtonen, A. (2017). Pirullisen ongelman äärellä: kokonaisvaltaisen ilmastokasvatuksen malli. Kasvatus, 48(5), 456-468.

Tolppanen, S., Claudelin, A. \& Kang, J. (2020). Pre-service teachers' knowledge and perceptions of the impact of mitigative climate actions and their willingness to act. Research in Science Education. https://doi.org/10.1007/s11165-020-09921-1

Värri, V.-M. (2018). Kasvatus ekokriisin aikakaudella. Tampere: Vastapaino. 